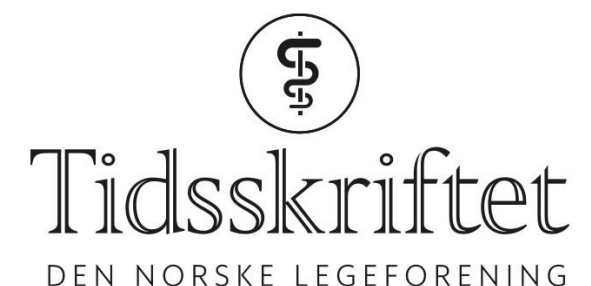

DEN NORSKE LEGEFORENING

\title{
Brev fra sanatoriet
}

I TIDLIGERE TIDER

BERIT NICOLAYSEN

E-post: bnicolaysen@gmail.com

Berit Nicolaysen er sosiolog. Hun er datter av Frants Nicolaysen, som er forfatter av brevene.

Dette er utdrag fra brev min far Frants Nicolaysen skrev til min mor Liv midt på 19oo-tallet, da han hadde tuberkulose og var innlagt på sykehus sammenhengende i fem år.

Frants lå på sykehus fra 1949 til 1953, de fire siste årene på Kysthospitalet i Tromsø. Han var 31 år, og jeg 2 år, da han ble syk. Min far kom fra Jakobsbakken i Sulitjelma, et lite gruvesamfunn i høyfjellet i Fauske kommune, der jeg bodde med min mor. Å reise til Tromsø var tungvint og dyrt. Hun besøkte ham to ganger og jeg én. Brevene ble det som bandt oss sammen. Når de kom, leste min mor deler høyt for meg. Slik ble jeg kjent med faren min.

\section{7. september 1951}

Morn! Jeg er nettopp ferdig med morgentoilettet, nybarbert og stelt og føler meg da godt opplagt til å ta fatt. Det er så trivelig nu å våkne om morgenen da jeg etter vasken blir så godt humør til å gjøre noe. På rom 1 var det et skrål og skrik så det var bare å dra puten fortest mulig over hodet igjen.

\section{0. mars $195^{2}$}

Det var så koselig å lese ditt siste brev. Takk for at du har så god tro. Det hjelper også meg. Har blitt valgt til formann i pasientforeningen og har dermed fått endel å stå i med. Det går mye tid til dette arbeidet, men det er jeg glad for. Får komme i kontakt med nye ting som gjør at dagene ikke blir fullt så gråe.

\section{0. april 1952}

Kjæreste Liv, om syv dager har du bursdag! Atter en gang, og solen vandrer fortsatt over de samme fjell. Jeg rett og slett lengter meg hjem til deg. Orker ikke tenke på årene.

\section{0. juli 1952}

Det ble så uendelig tomt etter deg. Dagene ble lange da jeg ikke hadde deg å vente på når klokken nærmet seg 4. En hel vinter har jeg ligget og ventet på at sommeren skulle komme, plutselig er den der - noen kjære dager - og så er det hele over, men dog med fornyet styrke og mot til å hold ut. Ja, det skal være visst at det hjelper meg kolossalt at du kommer hit. 


\section{7. november 1952}

Du har nu gått 4 år uten mann. Går slikt virkelig an og er det rett? Jeg har stilt meg det spørsmålet mange ganger. Hvis du fant en mann som du kunne like, er det så rett av meg å forlange at du skal vente og vente? Det går rundt som karusellen. Min lengsel etter deg er sterkest, og kveler min fornuftige tanke som så gjerne vil ditt beste. Og nu ligger jeg som før, venter som du - bare venter.

Her på huset driver vi nu på med litt av hvert. I vårt styre har vi behandlet den nye trygdeordningen, den såkalte folketrygden. Mitt brev til Stortinget, med styrets tilslutning, gikk sterkt inn for dette. Ellers har vi fått i oppdrag å arrangere en reportasje herfra på julaften med direkte sending over norsk rikskringkasting.

Det er måne hver kveld nå. Den skinner og skinner. Snart er det jul også. Det er visst en eller annen som har sagt at å forsake er veien til å bli lykkelig. Kan det stemme?

\section{6. desember 1952}

Det er ikke det at jeg får stå opp med det aller første, men idag kan jeg for første gang skrive og gi gode nyheter. Desto mer hyggelig er det at det ble til en julehelg, da en liksom trenger den enda mer enn vanlig. Selv er jeg så glad at det er vanskelig å forklare. Men på en slik forunderlig måte. Idag ble jeg hentet. Det er klart, at når man ligger så lenge og det ikke skjer nevneverdig framgang er det vanskelig for legen å vite hva han skal svare - eller fortelle pasienten hvordan stillingen er. Dette har vært grunnen til at jeg ikke har villet spurt. Med meg selv har jeg visst hvordan det var. Underforstått har både legen og jeg lest hverandres tanker etter hver kontroll. Det har ikke vært nødvendig med noen spørsmål. Idag undersøkte han først såret og forsøkte å stikke for å undersøke om det var noen kanal. Selv med en tynn nål kom han ikke inn. «Dette ser meget bra ut». Selve såret vil gro fort når bare det gror innvendig fra! Og det beste av alt. For første gang siden jeg kom inn er prøvene fra ryggen minus!! Og dette er jo betingelsen for at skaden i det hele tatt skal bli leget. Også prøven fra lungen var minus. Tenk hvor det letter å vite at det nu kan skje at vi får komme sammen igjen. Hele tiden har jeg ligget og ventet på denne stunden, og nu er den kommet. Jeg greide ikke vente til i kveld med å skrive, men gjør det nu, selv om her vrimler av vaskekjerringer mellom bord og senger. 


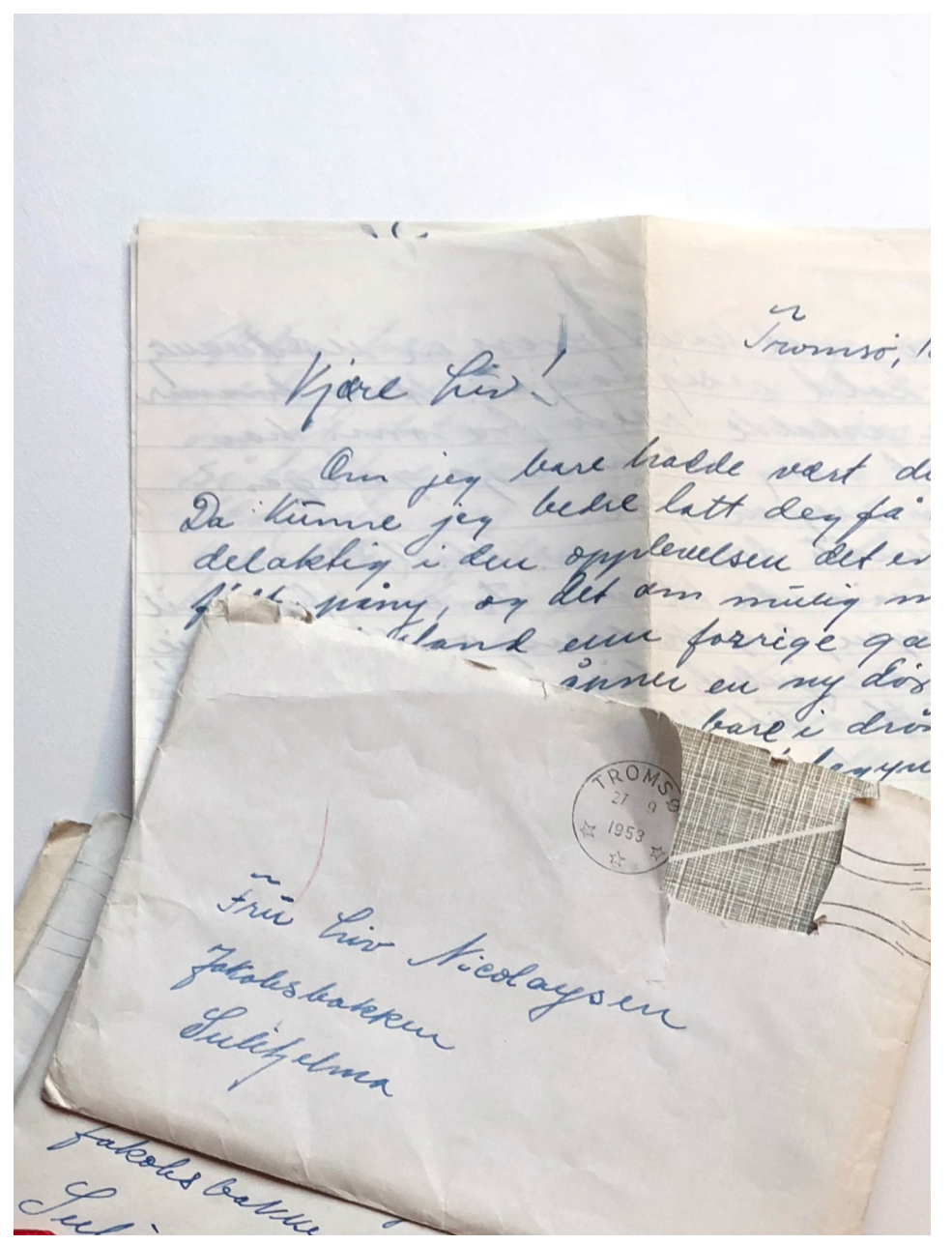

Det var meningen at jeg skulle si noen ord i kringkastingen julaften og dette har jeg ikke hatt noen lyst til, men nu tror jeg at det må prøves likevel. Om det blir slik, kan jeg jo ikke snakke til noen bestemt, men jeg skal tenke på at det er deg jeg snakker til. Da tror jeg det går lettere enn om tankene mine skal gå til store byer, fine folk og slikt. Og nu ønsker jeg dere en riktig god jul. Ja det gjør jeg med et mye lettere hjerte enn noe år før.

\section{6. januar 1953}

Skitt, jeg sier det. Det utrolige har hendt: Jeg har fått spesialseng! Til å begynne med var jeg bestemt på å holde dette hemmelig, da jeg var redd for at du kunne bli lei og utålmodig av å vente så lenge før jeg fikk opp. Ja tenk nu ligger jeg i spesialseng og skal stå opp. Er det ikke rart? Nu har jeg ikke rede på hvor lenge jeg må stå, men det får bli som det vil. Noen står i $1 \mathrm{mnd}$, andre har stått opp til $9 \mathrm{og} 10 \mathrm{mnd}$.

For noen dager siden var jeg oppe hos overlegen og da slengte han ut en bemerkning om at jeg skulle få begynne å stå, men jeg torde ikke å spørre om hva han sa. Trodde ikke mine egne ører. Så kom han da på visitt idag mens vi spiste. Sist kom turen til meg. Han kikket på kurven. Hjertet begynte å banke! Ble det seng? Konfererte litt med søster om ryggen, så på den mens jeg lå på maven. Han gikk tilbake til kurven. Så sa han det. «Vi får finne en annen seng til han!» Det surret i ørene mine; annen seng; spesialseng; annen seng; spesialseng. Fremdeles lå jeg på maven da han hadde skrevet det på kurven og gikk forbi på tur ut. Da sa han lett henslengt: «De får skifte over i en annen seng!» «Takk for det!» Dermed gikk han ut døren og klappsalvene braket løs, som de pleier gjøre ved slike begivenheter på stuen. Og så var i grunnen 1. akt over.

For en vidunderlig følelse det var å få bli lettet opp. Akkurat som å bli løftet fra noe dypt og mørkt og opp i lyset. Ja slik virket det faktisk. 


\section{7. mai 1953}

I dag sa overlegen på visitten at han skulle slippe meg opp!! Allikevel kan det bety at jeg må ligge 1 mnd, slikt vet en aldri. Når jeg ikke har spurt før er det fordi jeg vil ikke mase om å få stå opp.

Så har jeg fått spørsmål fra Korrespondanseskolen i anledning et kurs jeg har avsluttet (Særs godt) om å få bruke mine uttalelser til sine offentlige brosjyrer og de ville i så tilfelle gjerne ha et bilde. Om det jeg har sagt kan være til stimulanse for andre som ligger, skal de gjerne få lov, men bilde har jeg ikke lyst å få satt inn. Ikke har jeg noen heller.

\section{Kysthospitalet på Tromsø, overlægen, 10. juni 1953}

Frants ble operert i går, og operasjonen gikk helt fint. Den var ganske kortvarig, 1 time og 10 min. Det var nemlig ikke så meget med ham. Meningen var at han ikke skulle opereres, men for ikke å risikere at han kanskje senere ville få et opphold her igjen, fant overlegen det best å operere. Temp. var 37,5 i morges, og det er ingenting etter en operasjon.

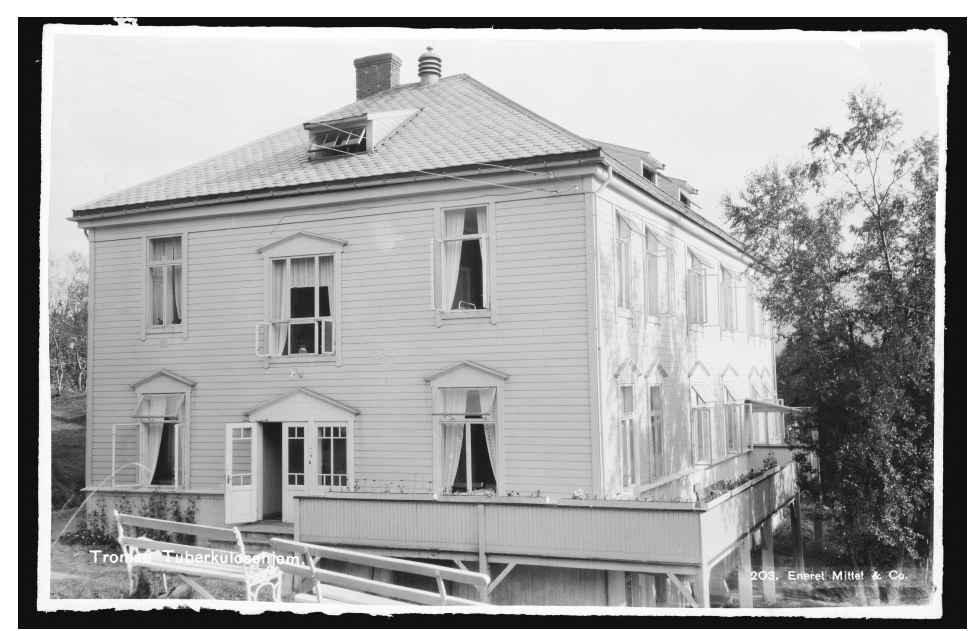

Tromsø Tuberkulosehjem, et av flere tuberkulosesykehus i fylket i den perioden. Foto: Mittet $\mathcal{\sigma}$ Co/Nasjonalbiblioteket.no

\section{6. juni 1953}

Ja nu er det gjort. Så fort tiden går. Det var nesten en opplevelse å bli operert. Forresten den husker jeg jo ikke, men bedøvelsen, og før jeg sovnet inn. Da oversøster er borte måtte jeg eterbedøves. Lystgassen er det bare hun som kan gi. Det kom litt mye til å begynne med inn i munnen som jeg ikke greide å svelge unna og da var det vondt; eller rettere sagt vemmelig. Men siden gikk det så veldig lett å puste. Akkurat som alt sammen bare skulle være en stor åpning for luften. Jeg pustet dypt inn. Så sa søster «Bind hendene. Nu må du sove Nicolaysen».

Alt ble stille, så kom det for meg en stor sal hvor alt klang så stille og hult. Hørte overlegens tørre stemme. Så var det noen som kneppet på en maskin om og om igjen. Så om en stund husker jeg søsteren tittet på meg. Hun satt som en mumie med to uttrykksløse glassøyne og stirret på meg. Det var bare øynene som vistes for bindet foran munnen gikk helt opp. En trøtt slepende stemme sa: «Er jeg ferdig, søster Else?» «Nu må du sove. Pust riktig godt.» Antagelig har jeg fått litt mer eter da. Kl 12.30 våknet jeg på enerommet. Da var jeg litt uvel etter all eteren. Men lite vondt har jeg hatt og temp. var 38.2 dagen etter. Ellers var den helt normal allerede på fredag. Idag skal jeg kjøres på rom 1 igjen. Det har vært en deilig uke her. Stille og fredelig. Jeg har ikke hatt på radioen en gang.

\section{5. september 1953}

Takk både for denne og forrige tikrona. Som takk for det kvitterer jeg med: spesialseng! Siste dag før overlegen reiste til Oslo fikk jeg den. Liv, det kjentes underlig! Skal jeg virkelig 


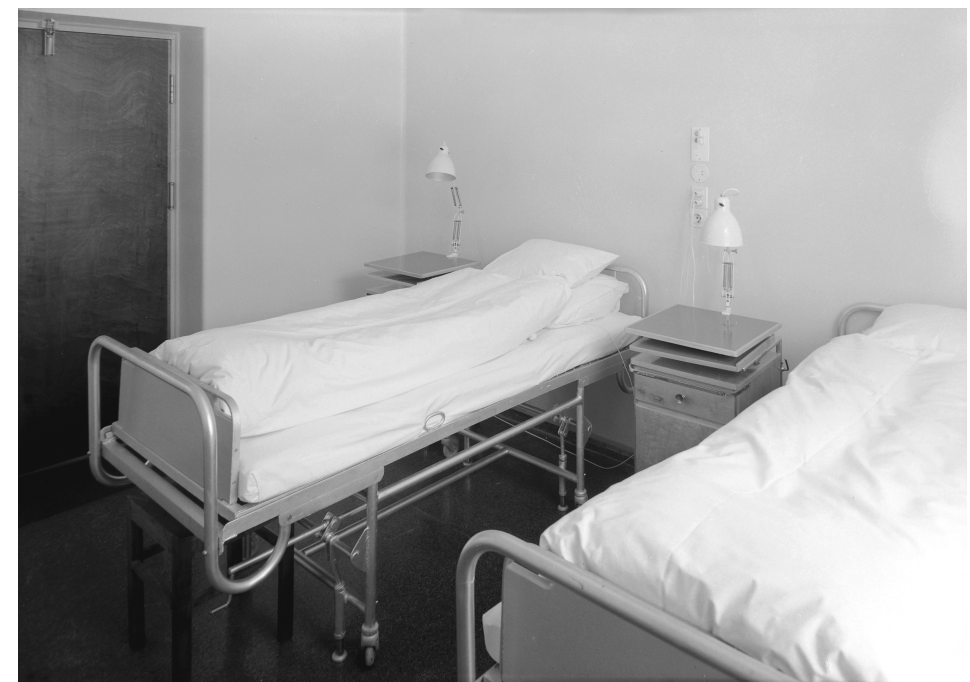

Man kan se for seg at Frants Nicolaysen bodde på et rom som ligner dette. Bildet er tatt 1952 på Ringvål sanatorium i Trøndelag. Foto: Sverresborg Trøndelag Folkemuseum

\section{8. november 1953}

Om jeg bare hadde vært dikter! Da kunne jeg bedre latt deg få være delaktig i den opplevelsen det er å bli født på ny, og det om mulig med litt mer forstand enn forrige gang.

Verden åpner en ny dør for hver dag, inn til det nye, som bare i drømme har vært en vag anelse. Det begynte med første visittdagen etter overlegens hjemkomst da det for meg historiske, lenge ventede øyeblikk kom: «Da han skulle bla gjennom kurvene, klemme på maven og legger, og så vende tilbake til kurvene, bomme tre-3-ganger på rødblyanten, som var lett synlig, før han traff, legge ansiktet i de rette folder, mens det som vanlig under slike seremonier var helt stille på stuen, mens han utfører sine bestemte, rytmiske bevegelser som etterlater seg en lang rød pil loddrett på kurven». Der satt endelig pilen. Hjertet hoppet og danset i allverdens utakt under disse endeløse sekunder og jeg måtte anstrenge meg for at ikke hjertet skulle hoppe av sporet. Likevel kjente jeg som så ofte før under situasjoner med hardt press en usedvanlig ro og kald resignasjon. Hvor kommer denne iskalde roen fra som har hjulpet meg så mange ganger? Det er meg en gåte. Dette hendte den 16. november $\mathrm{kl}$ 1130. Og da vi enda til var to som fikk pil den dagen, to spesialseng og fire maveleie, braket en jubel løs som aldri ville ta slutt. Til kvelds hadde vi pølsefest.

Og hvordan skal jeg så få til å fortelle om alle de inntrykkene som trengte på, langt mer ta dem i den rette rekkefølge? Nei, forresten, jeg tror ikke det var spørsmål om tur. Antagelig trengte alt på fra alle vinkler. Tenk bare på for en følelse det var å få stå og vaske seg med iskaldt rennende vann i ansiktet! Det var det første jeg gjorde. Så kom turen til buksene, ja underbuksene også, strømper og sko. Gå, helt fri! Hvor en ville etter som tungen la seg. Ja, det eiendommeligste var likevel å sitte på klosettet. Der satt NN [anonymisert av redaksjonen] og jeg på hvert sitt og undret oss over den verden vi så plutselig var kommet inn i. Og så sitter vi til bords og spiser pent, med kniv og gaffel. Aldri har jeg oppført meg så pent ved spisebordet før, og vi er enige om at aldri har noen av oss vært så høflige før! Tenk, sitte og spise! I dag var jeg ute på marken og da kjente jeg det knase i stein under skoene. Herlig følelse som minte om gode gamle turer.

Jeg får ikke sove om kvelden. Så mye strømmer på, og det verker så irriterende søtt i leggmusklene. Nede på sengegavlen henger buksene. Når jeg vil kan jeg slenge beina utfor sengkanten og hoppe i dem. Gå - og være fri. De som ikke har prøvd, vet ikke hva frihet er. Det er den største og kjæreste drift i mennesket, sånn bort i mot iallfall. Så ligger jeg og koser meg og tenker: «Skal jeg stå opp nå? Nei, jeg ligger en stund til! Nå står jeg opp!» Vaske seg, barbere seg, få på seg rene, nye klær. Livet er deilig! Alle følelser greier jeg enda 
ikke registrere fra hverandre. Men jeg må ta med at bare det å sitte og skrive er et vidunder.

Jeg er utrolig sprek etter omstendighetene. I går kveld gikk NN og jeg rundt og hilste på pasientene på stuene. Kaffen putret, og vi serverte. Vi nøt hvert minutt. Vi solte oss i glansen av å være dagens midtpunkt. Det er alle på sin første rundtur. I dag var det min tur. Hvor mange hadde ikke jeg vært med å gratulere? Vi fortalte om våre nye inntrykk og nye verden. På en stue angrer jeg i dag på det. En eldre dame som har ligget 7-8 år har liten sjanse å få komme ut. Hun har et utrolig humør, men jeg tenkte i natt på at ble ikke hun litt stille da jeg fortalte? Jeg tror jeg angrer på det. På hjemveien kjørte vi med «trikken» som kåte guttunger opp og ned flere ganger. Vi kniste og lo som man gjør i den alderen.

Liv, kjære du, kanskje har jeg ringt når du får dette. Vær snill å gjem dette brevet, så jeg engang får se og oppleve dette på nytt. Nå går posten og lev vel du og Berit.

En måned etter at dette brevet ble skrevet kom Frants med Hurtigruten til Bodø midt på natten. Liv sto på kaia. De vandret arm i arm i desemberkulden til morgenen kom. Så dro de hjem til Sulitjelma der jeg ventet på dem. Han ble helt frisk, og vi fikk nesten 30 gode år sammen før Frants døde i 1982, 64 år gammel.

Publisert: 10. desember 2018. Tidsskr Nor Legeforen. DOI: 10.4045/tidsskr.18.o747

(C) Tidsskrift for Den norske legeforening 2020. Lastet ned fra tidsskriftet.no 